\title{
Religiões Afro-Brasileiras do Rio Grande do Sul: Passado e Presente*
}

Ari O ro

Resumo

0 texto divide-se em duas partes. A primeira apresenta dados sobre o período escravocrata no R io G rande do Sul, a estruturação das religiões afro-brasileiras (Batuque, U mbanda e L inha C ruzada) nesteestado eo histórico econtrovertido papel desempenhado no Rio G rande do Sul por um príncipe africano queaqui viveu do final do século XIX até 1935. A segunda parte analisa três aspectos particularmente importantes na atualidade dessas religiões neste estado: a presença de não-negros nas mesmas, a sua expansão transnacional para a Argentina e o U ruguai, e 0 estreitamento de relações com o poder político local..

Palavras-chave: Batuque, negro, relações raciais, Rio Grande do Sul, Brasil, religiões afro-brasileiras.

* Este texto foi originalmente apresentado na 53ª Reunião Anual da Sociedade Brasileira para o Progresso da Ciência (SBPC), realizada em Salvador, Bahia, de 14 a 17 de julho de 2001, no Simpósio: Afro-D iversidade no Brasil, coordenado por Reginaldo Prandi (USP).

Estudos Afro-Asiáticos, Ano 24, № 2, 2002, pp. 345-384 
Arioro

Abstract

Afro-Brazilian Religions in Rio Grande do Sul: Present and Past

The article is divided into two parts. The first presents data about the slavery period in Rio G rande do Sul, the structure of Afro-Brazilian religions (Batuque, $U$ mbanda and Linha Cruzada) in this state and the historical and controversial role played by an African prince who lived here from the late $19^{\text {th }}$ century until 1935 . The second part analyses three particularly important aspects of these religions in Rio $\mathrm{G}$ rande do Sul nowadays: the presence of non-N egroes in them, its transnational expansion to Argentina and U ruguay, and the ever-close relations with local political power.

Keywords: Batuque, N egro, racial relations, Rio Grande do Sul, Brazil, Afro-Brazilian religions.

Résumé

Les Religions Afro-Brésiliennes de l'É tat du Rio G rande do Sul:

d'H ier et d'Aujourd'hui

Le texte se divise en deux parties. La première présente des données sur la période de l'esclavage dans le Rio G rande do Sul, la structuration des religions afro-brésiliennes (Batuque, U mbanda et Linha C ruzada) dans cet état ainsi quelerôlehistorique et controverséqui y a jouéun prince africain de la fin de XIX ème siècle jusqu'à 1935. D ansla seconde partie, nous analysons trois aspects particulièrement importants pour I'actual isation des ces religions dans cet état: la présence de non-N oirsà ces religions, leur expansion transnationale vers l'Argentine et I'U ruguay, ainsi que leur relation étroite avec le pouvoir local.

M ots-clés: Batuque, N oir, relations raciales, Rio Grande do Sul, Brésil, religions afro-brésiliennes. 
$\mathrm{N}$ este texto apresento alguns tópicos relativos às religiões afro-brasileiras do Rio G rande do Sul (RS) que contemplam ao mesmo tempo uma visão histórica e atual, com ênfase nas suas características que mais se destacam na atualidade.

I nicio com dados historiográficos sobre o ingresso do negro escravo no RS e sobre a estruturação do Batuque. D iscorro então sobre os distintos "Iados" desta religião ao mesmo tempo em que aponto al guns aspectos históricos e especificidades da U mbanda e da Linha C ruzada neste estado. Em seguida, me atenho a um personagem legendário do campo afro-gaúcho, um príncipe africano que residiu neste estado a partir de 1899 e aqui faleceu em 1935. $\mathrm{N}$ a seqüência, discorro sobretrês importantes características atuais do campo religioso afro-gaúcho, a saber: a presença de "brancos" nas rel igiões de matriz africana; a transnacionalização do batuque e demais religi ões afro-brasileiras para os países do Prata; e a aproximação dessas religiões no campo político estadual e municipal, sem, porém, ocorrer o ingresso efetivo na esfera política, como fazem, por exemplo, os evangélicos.

Os N egros e as Religiões Afro-Brasileiras no Rio Grande do Sul

O snegros africanos e seus descendentes partici param diretamente do desenvolvimento econômico dos dois primeiros séculos da história do Rio G rande do Sul. Segundo Beatriz Loner, "praticamentenão houve profissão manual que não tivesserepresentantes dessa etnia em seu desempenho, tanto no período imperial quanto na República" (Loner, 1999:9). 0 mesmo, como se sabe, ocorreu nas demais capitanias e províncias do Brasil onde, como diz Prandi, os escravos africanos "foram sendo introduzidos [... ] num fluxo que corresponde ponto por ponto à própria história da economia brasileira" (Prandi, 2000:52). ${ }^{1}$

0 marco inaugurador do Rio G rande do Sul éa fundação do Forte de Jesus, M aria e José, na Barra de Rio Grande, no ano de 
1737, pelo brigadeiro J osé da Silva Paes, em cuja tropa, formada por 260 homens, havia escravos e negros libertos.

A historiografia do Rio G rande do Sul ainda se debate em torno da questão de saber a procedência do negro escravo trazido para este estado. $\mathrm{H}$ á, no entanto, al gum consenso de que essa população se dividia entre negros "crioulos", ou seja, indivíduos nascidos no Brasil e para aqui transferidos, "ladinos", isto é, indivíduos quejá haviam trabal hado em outras regiões do país, e africanos, aqui chegados após terem passado por al gumas regiões brasileiras, entre elas, Bahia, Pernambuco, São Paulo, Santa C atarina, e mesmo africanos que chegaram ao Rio $\mathrm{G}$ rande do Sul provenientes da Argentina e do U ruguai. A título de exemplo, um levantamento realizado junto aos I nventários da F reguesia de Pelotas, no período compreendido entre 1850 e 1880, mostrou que num universo de 1.604 escravos, 460 eram crioulos, 556 indeterminados e 590 africanos (Assumpção, 1990). Estes últimos, por sua vez, dividiam-se em diferentes nações ou grupos tribais. Por exemplo, por ocasião das comemorações da A bolição, desfilaram em Pelotas os "Filhos de Angola, M ina, Benguela, Erubé, Congo e Cabinda..." (Jornal Echo do Sul, 10/6/1888 apud Loner, 1999:8). ${ }^{2}$ Seja como for, no Rio G rande do Sul "os banto vieram em número muito superior aos sudaneses" (C orrea, 1998a:66).

A introdução do escravo no RS ocorreu a partir da primeira metade do século XVIII. Trabal havam na agricultura, nas estâncias e, sobretudo a partir de 1780, na produção do charque, na região de Pelotas. Segundo Correa, os negros compunham cerca de 30\% da população da Província em 1780, e40\% do total em 1814. $\mathrm{N}$ esta data, os negros perfazem cerca de $51 \%$ da população dePiratini e 60\% dePel otas (ibidem:65-66). Porém, com o início da chegada dos colonos al emães em 1824 e dos italianos em 1875, verifica-se um aumento da população branca e uma redução na porcentagem da população negra em território gaúcho.

A produção das charqueadas - executadas pelo trabalho braçal escravo em condições bastante desfavoráveis em razão das condições climáticas, precariedade de infra-estrutura e exigências severas ditadas pelo próprio regime escravocrata - foi de tal monta queem 1861 o charque contribuía com $37,7 \%$ do total do queo RS exportava e os couros com $37,2 \%$ do total, juntos somando $74,9 \%$ do total da produção gaúcha para fora da Província (Assump ção, 1990). A relação entreo trabalho forçado dos negros e 0 desenvolvimento das charqueadas era tal que na medida em que se aproximava a Abolição também diminuiu o número de 
charqueadas. Assim, referindo-se a Pelotas, Loner lembra que "de um total de 34 charqueadas existentes em 1878 na cidade, elas reduziram-se a apenas 21 às vésperas da Abolição e a 18, dois anos depois" (Loner, 2001:7), ocasionando a diminuição do charque que servia de alimento dos escravos do sudeste e desta forma acarretando problemas no mercado de consumo deste produto.

A estruturação do batuque no Rio Grande do Sul constitui outro tema que aguarda um aprofundamento investigativo. Tudo indica que os primeiros terreiros foram fundados justamente na região de Rio Grande e Pelotas. Para o historiador Marco Antônio Lirio de Mello - que fez uma ampla pesquisa nos jornais de Pelotas e Rio Grande do século XIX — a presença do batuque é atestada nesta região desde o início do século XIX (Mello, 1995). Também Correa situa o período inicial do batuque nesta região entre os anos de 1833 e 1859 (Correa, 1988a:69). Se assim for, permanece a dúvida de se saber se a estruturação do batuque ocorreu posteriormente ou paralelamente à estruturação do candomblé, uma vez que o primeiro terreiro de candomblé teria surgido na Bahia no ano de 1830 (Jensen, 2001:2). Aliás, a mesma dúvida M. Herskovits havia levantado em 1942, por ocasião de uma "rápida viagem" pelo Rio Grande do Sul (Herskovits, 1948). ${ }^{3}$

No entanto, a partir das décadas de 70 e 80 do mesmo século, os jornais dessa região apresentam, com alguma regularidade, em suas páginas policiais, matérias sobre cultos de matriz africana. De fato, nos jornais Correio Mercantile Jornal do Comércio, de Pelotas, bem como no jornal Gazeta Mercantil de Rio Grande, pode-se ler notícias, infelizmente as mais recorrentes sendo de prisão de "feiticeiros" e "feiticeiras", como esta:

Foram presas à ordem da delegacia, duas pretas feiticeiras que atraíam grande ajuntamento de seus adeptos. Na ocasião de serem presas, encontrou-se-lhes um santo e uma vela, instrumento de seus trabalhos [...]”. (Jornal do Comércio, Pelotas, 9/4/1878, p. 2 apud Mello, 1995:26)

Quanto ao mito fundador do batuque, há duas versões correntes: uma que afirma ter sido o mesmo trazido para esta região por uma escrava, vinda diretamente de Recife; e outra que não associa a um personagem, mas às etnias africanas que o estruturaram enquanto espaço de resistência simbólica à escravidão.

Já as notícias relativas ao batuque em Porto Alegre ${ }^{4}$ datam, preferencialmente, da segunda metade do século XIX, isto sugerindo que ou sua origem, ou, o que é mais provável, o seu incremento pode ter ocorrido com a migração de escravos e ex-escravos 
da região de Pelotas e R io G rande para a capital. N ovamente, as principais fontes de referência são os jornais que reportam ações policiais contra os terreiros. Lilian Schwarcz transcreve, por exemplo, reportagem do Correi o Paulistano, de 30/11/1879, intitulada "O s feiticeiros do RS - G rande C açada". D iz a reportagem:

a polícia tomou ontem em uma casa 42 pretos livres e escravose 11 pretosminas. A caçada deu-seàs $10 \mathrm{~h} 30$ da noiteno momento em que o preto João cel ebrava uma sessão de feitiçaria. Foi uma surpresa e um desapontamento que aqueles fiéis crentes jamais perdoarão a polícia [...]. A polícia apreendeu cabeças de galo e outros manipansos. Os principais atores da indecente comédia foram recolhidos à cadeia e os escravos castigados. (Schwarcz, 1989:126, ênfases minhas)

Inútil dizer que as perseguições aos terreiros não deixam de expressar um certo medo branco diante do poder de manipulação das forças sobrenaturais por parte dos escravos e seus descendentes. O bviamente que a perseguição era sempre precedida de um conjunto de estigmas lançados sobre essas religiôes, visando justificar aquele procedimento.

Em Porto Alegre, a partir da segunda metade do século XIX, o maior contingente denegros se en contrava nas cercanias da cidade, no Areal da Baronesa, na cidade baixa, imediações da atual Rua Lima e Silva, e nas chamadas Colônia Africana e "Bacia", atuais bairros Bonfim, M ont Serrat e Rio Branco. ${ }^{6}$ Estas últimas tratavam-se, em sua origem ("em torno da época da abolição"), de uma "zona insalubre, localizada nas bordas de chácaras e propriedades queali existiam, de baixa val orização ede pouco interesse imediato para seus donos, que foi sendo ocupada por escravos recém-emancipados" (Kersting, 1998:111). ${ }^{7}$

Kersting mostra como, sobre essas áreas, foram criadas representações que as associavam a criminalidade, vícios, perigo, e seus habitantes tidos como membros de "classes perigosas". Por isto mesmo, essas áreas foram deixadas a um relativo isolamento por parte das autoridades públicas e, ao longo das décadas do século passado, foram dissolvidas medianteum processo de "higienização urbana" ${ }^{8}$ Evidentemente que por trás desta atitude existiam interesses imobiliários de ocupação dessas áreas da cidade para "modernizá-las", o que começou a ocorrer ainda nas primeiras dé cadas do século XX, com o processo de branqueamento da população, simultaneamente à abertura de ruas e de construções em padrões arquitetônicos não populares. Por exemplo, parte da Colônia Africana começa a receber iluminação elétrica em 1911, algu- 
mas ruas são asfaltadas em 1912 e neste momento prevê-se também a construção de uma rede de esgotos. R eitero que esse processo de urbanização consiste fundamental mente na descaracterização como área essencial menten egra "atése transformar em bai rro saneado que se vê em 1922" (ibidem:195). Esteautor informa que a maioria dos não-negros quefixam residênciana ex-Colônia Africana são judeus, enquanto os negros são expulsos para áreas mais periféricas e ainda desabitadas, como o bairro M ont Serrat, destino primeiro dos exilados da Colônia Africana e onde al gumas famílias conseguiram estabelecer moradia até os dias de hoje. ${ }^{9}$

Simultaneamente a esse processo de modernização, justamente em 1912 a Colônia Africana passa a ser um bai rro chamado Rio Branco. Embora seja uma homenagem ao Barão do Rio BranCo, não deixa deser irônico queum território anteriormentedenominado C olônia Africana, em razão da presença maciça de negros, seja chamado de Rio Branco, caracterizando o predomínio de não-negros nesta área.

H á relatos da prática de cultos afro-brasileiros em todos os territórios negros referidos. Relativamente à Colônia Africana, por exemplo, o primeiro sacerdote da igreja de N ossa Senhora da Piedade, concluída e inaugurada nesta área em 1913, cônego M atias W agner, "aponta para a presença desses cultos e para o fraco número de católicos realmente fiéis" (ibidem:184). Assim, em seu livro "Paróquia de N . S. da Piedade de Porto Alegre:1916-1958", o referido cônego escreve: "Encontrei certa vez um homem que, dizendo-semuito católico, apostólico eromano, era também dono ePai Santo de uma casa de batuque..." (apud Kersting, idem:186). 0 mesmo cônego refere também que foi alvo de despachosde "parte daquela gentedeU mbanda". Aliás, o pároco se refereàs religiões afro-brasileiras pel os nomes de batuque, umbanda e espiritismo e, mais genericamente, pelos termos etnocêntricos e preconceituosos de crendices, superstições e feitiçarias.

No contexto das lacunas históricas sobre as religiões afro-brasilei ras no Rio G randedo Sul figuram também dados estatísticos sobre os terreiros deste estado. D ispomos unicamente de informações parciais sobre o número de terreiros de batuque para Porto Alegre, durante 20 anos, de 1937 a 1952, apresentados por Carlos Krebs (1988:16).

Tais dados constam das estatísticas oficiais do Rio G rande do Sul, tendo o censo sobre a religião sido abandonado em 1952. $M$ algrado sua precariedade, pode-se perceber um crescimento quase que anual do número de terreiros em Porto Alegre, fato este 
Ari O ro

Casas de Batuque em Porto Alegre

\begin{tabular}{cc}
\hline Anos & Total de C asas \\
\hline 1937 & 13 \\
1938 & 23 \\
1939 & 27 \\
1940 & 37 \\
1941 & 42 \\
1942 & 52 \\
1943 & 80 \\
1944 & 63 \\
1945 & 70 \\
1946 & 75 \\
1947 & 78 \\
1948 & 80 \\
1949 & 80 \\
1950 & 98 \\
1951 & 178 \\
1952 & 211 \\
\hline
\end{tabular}

que continua, segundo dirigentes de federações, até os dias de hoje, onde existem, no seu conjunto, cerca de dois mil terreiros na capital gaúcha.

\section{O Batuque}

Batuque é um termo genérico aplicado aos ritmos produzidosà base da percussão por freqüentadores de cultos cujos elementos mitológicos, axiológicos, lingüísticos e ritualísticos são de origem africana. 0 batuque é uma religião que cultua doze orixás ${ }^{10} \mathrm{e}$ divide-se em "lados" ou "nações", tendo sido, historicamente, as mais importantes as seguintes: 0 yó, tida como a mais antiga do estado, mas tendo hoje aqui poucos representantes e divulgadores; Jeje, cujo maior divulgador no Rio Grande do Sul foi o Príncipe Custódio, sobre o qual falaremos mais abaixo; Ijexá, Cabinda e $\mathrm{N}$ agô, são outras nações de destaque neste estado. $\mathrm{N}$ ota-se que 0 K eto esteve historicamente ausente no RS, vindo somente nos últimos anos a se integrar por meio do candomblé.

Vejamos al guns dados disponíveis sobre as mencionadas nações neste estado: 
OYÓ. Segundo a tradição local, esta nação chegou a Porto Alegre vindo da cidade de Rio G rande. Foi cultuada no Areal da Baronesa edali no M ont Serrat onde se situaram as principais casas deste culto.

M. H erskovits e R. Bastide, por ocasião de suas estadas em Porto Alegre, o primeiro em jul ho de 1942 e o segundo em 1944, referem-se carinhosamente à $M$ ãe Andrezza Ferreira da Silva, da nação 0 yó que, segundo Bastide, "formara-secom um velho babaIorixá que ainda tinha à sua volta al guns africanos nativos" (Bastide, 1959:238). Segundo Carlos K rebs, M ãe Andrezza teria vivido de 1882 a 1951 (K rebs, 1988).

$\mathrm{H}$ oje, como disse acima, trata-se de um culto praticamente em extinção, restando algumas poucas casas no estado. Segundo Pernambuco N ogueira,

[...] o último nome da antiguidade da nação 0 yó que conhecemos foi Tim do 0 gum, já fal ecido, eque foi o iniciador da $D$ el sa do 0 gum, casa ainda em atividade. Além deste vamosencontrar o Antoninho da 0 xum esua filha-de-santo a M oça da 0 xum (Lídia G onçalves da Rocha), como nomes de projeção. D istinguiu-se entre os praticantes do 0 yó a figura de Fábio da 0 xum quer pela beleza e suavidade do orixá que recebia, quer pel o fato deter sido um dos raros pais-de-santo quenão vivia da R el igião (N ogueira, 2001b).

As especificidades da nação 0 yó residiam, sobretudo, na ordem das rezas, uma vez que chamavam primeiro os orixás masculinos e a seguir os femininos, encerrando-se com as de Yansã ( 0 iá), Xangô efinalmente 0 xalá, o destaque para os dois orixás resultando do fato de serem o Rei ea Rainha de 0 yó. Também era próprio da nação 0 yó os orixás conduzirem em suas bocas, ao término das obrigações, as cabeças dos animais oferecidos em sacrifício já em estado de decomposição; finalmente, segundo os mais antigos, no 0 yó osocutáseram enterrados, em vez de colocadosem pratelei ras (ibidem).

IJ EXÁ. Trata-se da nação predominante hoje no estado. O s deuses invocados são os orixás ea língua ritualística éo iorubá. $R e$ nomados babalorixás históricos (já falecidos) como M anoelzinho do Xapanã e T ati do Bará, ambos iniciados na C abinda, passaram maistarde para o J ejeeseus descen dentesingressaram todosno ljexá, dizendo-se então Jeje-Ijexá.

Segundo um depoimento colhido por $\mathrm{N}$ orton Correa junto ao já fal ecido tamboreiro D onga de Yemanjá, o l jexá predominava 
nas regiões negras de Porto Alegre como o M ont Serrat e C olônia Africana (C orrea, 1998a:76).

JEJE. N o dizer de Pernambuco N ogueira,

[...] foi, durante muito tempo, a $\mathrm{N}$ ação quepredominou no $\mathrm{R}$ io $\mathrm{G}$ rande do Sul, em que pese o fato de jamais termos ouvido falar em voduns a exemplo dos cultuados em São Luis do M aranhão. Sempre ouvimos dos que se diziam jeje puros fal ar einvocar os orixás nagô. D ada a complexidadedosseustoques, a morosidade dos mesmos ea dificuldadena preparação dos tamboreiros que, inclusive, deviam usar os oguidavis, dedifícil manejo, foram adotando as rezas do l jexá [...]" (idem).

As figuras mais importantes desta nação foram Paulino do $O$ xalá Efan, que reiniciou no J eje o $M$ anoelzinho do $X$ apanã eT ati do Bará, oriundos da Cabinda, como disse acima. U m dos filhos de Paulino foi João Correia de Lima, Joãozinho do Bará Agelú, morador do M ont Serrat, talvez o primeiro e um dos mais importantes babal orixás que "exportou" o batuque para al ém dasfronteiras do R io G rande do Sul em direção aos países do Prata, como veremos abaixo. 0 utro importante babalorixá desta nação foi I dalino do 0 gum, que faleceu com a idade de 104 anos. Enfim, outro personagem, este mitológico, da nação Jeje foi o famoso Príncipe Custódio de Almeida, sobre o qual falaremos a seguir.

Vale aqui registrar que a origem do termo "jeje" é bastante problemática. L orand M atory, por exemplo, sintetiza uma série de autoresquetentam esclarecer o "mistério" em torno desteconceito e propõe a hipótese de que se trata de uma construção tran satlântica, ou seja, um nome aplicado pelos comerciantes e donos de escravos - alguns retornados, em suas idas e vindas entre Brasil, Cuba eG olfo da G uiné- "a todosos africanosqueeles consideraram seus parentes, apesar de ser pouco provável que esses 'parentes' assim se identificassem inicialmente" (M atory, 1999:64).

CABIN D A. T rata-se deuma nação Banto, originalmente de fala Kimbundo. 0 cemitério é o início da nação religiosa de $\mathrm{C}$ abinda, diz um pai-de-santo e estudioso do batuque. Segundo ele,

[...] o culto aosEguns nesta $N$ ação étão forte que dificilmente se encontrará uma casa-de-religião sem que tenha o devido assentamento de Balé (culto aos egunguns), ou I gbalé (casa dos mortos). (Ferreira, 1994:59)

Já para o babalorixá Pernambuco N ogueira, nos rituais de Cabinda que freqüentou no Rio G rande do Sul "jamais ouvimos falar de Inkices. 0 que sempre foi cultuado foi o 0 rixá iorubano" (N ogueira, 2001b). 
Segundo consta, este culto foi trazido para o R io G rande do Sul por um africano conhecido por G ululu, de cujas mãos saiu a figura mais marcante do culto C abinda no Rio G rande do Sul: W aldemar Antônio dos Santos, do Xangô K amucá. D ele descenderam as famosas M ãe M aria M adalena Aurélio da Silva, de 0 xum Epandá D emun, que iniciou Romário Almeida, do 0 xalá, e H enrique Cassemiro Rocha Fraga, de 0 xum Epandá Bomi, todos falecidos, eM ãe Pal mira Torres dos Santos, de Exum Epandá O lobomi, que iniciou J oão Cleon M elo Fonseca, do 0 xalá, queétido hoje como o mais importante herdeiro da tradição $\mathrm{C}$ abinda do estado, embora, como diz Pernambuco N oguei ra, "de sua origem mantém apenas o rótulo: o conteúdo é todo ele ljexá" (ibidem).

N AG Ô . N o dizer de Pernambuco N ogueira, [...] é uma nação que, tendo sido a origem do C ulto no Rio G rande do Sul, hoje está praticamente extinta, restando pouquíssimas casas" (idem). $\mathrm{H}$ á, em Porto Alegre, o terreiro N ova Era, do pai J ader, que pretende ser a continuação dessa tradição longínqua no estado. D iferentemente dos demais terreiros, neste, "a chegada dos orixás se faz como no Candomblé (linha por linha, trabalhando e desincorporando) e a matança é procedida com o animal no chão e não suspenso" (idem).

Ainda segundo Pernambuco N ogueira, "talvez situa-se nesta casa a semente do culto africano plantada pelos escravos das charqueadas, desde a sua origem em Rio G rande..." (idem).

Ao que consta, não dispomos de informações numéricas sobreaincidência dessas naçõesno Rio G rande do Sul. 0 historiador $D$ ante de L aytano, em pesquisa realizada sobre 0 batuque em Porto Alegre, em 1951, observou que as 71 casas por ele encontradas dividiam-se em 24 de nação N agô, 21 Jeje, 130 yó, 8 Ijexá e 5 "mistos" (Laytano, s.d.:53). N a atual idade, porém, predomina no batuque do Rio G rande do Sul o lado Ijexá, "quer pela facilidade do toque como pela ausên cia de tamboreiros iniciados nos demais Cultos" (N ogueira, 2001b). Embora haja terreiros que se digam seguidores de outroslados, trata-se, segund o o babal orixá Adal berto Pernambuco N ogueira, "apenas de rótulos utilizados talvez para marcar a origem dos fundamentos" (idem). ${ }^{11}$

\section{A U mbanda}

A primeira casa de umbanda no Rio G rande do Sul foi também fundada na cidade de Rio Grande, em 1926. Chamava-se 
"R eino de São J orge" e foi fundada pelo ferroviário $\mathrm{O}$ tacílio C harão.

Como em todo o Brasil, também no Rio Grande do Sul a umbanda surgiu defendendo padrões e comportamentos aceitos socialmente. No entanto, não escapou à repressão policial, a tal ponto, informa M. Caldas - um dos maiores intelectuais da umbanda e do espiritismo no Rio G rande do Sul, hojefalecido - que nos primeiros tempos o centro de C harão não possuía um endere ço fixo, funcionando de forma itinerante (seu endereço mudava toda semana). Também o próprio espiritismo e o batuque se opuseram à umbanda nascente, o primeiro desqualificando suas práticas mediúnicas, o segundo não aceitando que seus orixás fossem invocados sem suas normas rituais, o que denuncia que estava em jogo uma disputa de bens simbólicos (I saia, 1997:386).

D eRio G rande, a umbanda foi trazida para Porto Alegre, em 1932, pelo capitão da marinha Laudelino de Souza Gomes, que fundou nesta capital a Congregação Espírita dos Franciscanos de U mbanda, existente até os dias atuais. N este caso, é dupla a razão do termo franciscano. Em primeiro lugar, pela sincretização entre São Francisco de Assis e Lokô (termo yorubá), ou I rokố (termo jeje), ou orixá tempo (Angola), isto é, a árvore gamel eira branca; em segundo lugar, pelo uso que seus membros fazem de uma espé cie de bata branca, com sandália e cordão em torno ao ventre, semelhante ao que consta na iconografia histórica atribuída a São Francisco.

Pernambuco N ogueira esclarece que tanto Charão quanto Souza G omes não eram originários do R io $\mathrm{G}$ rande do Sul eambos estiveram na África por algum tempo. No entanto, dedicaram-se quase que exclusivamente à implantação e divulgação da U mbanda (N ogueira, 2001b). 0 utros importantes personagens divulgadores da umbanda neste estado foram $\mathrm{N}$ orberto de O liveira, quea introduziu no município de Viamão; J esina Furtado, fundadora da casa M estreQ uatro Luas; eAstrogildo deO liveira, fundador do Templo Rainha Yemanjá Fraternidade U birajara. Segundo Pernambuco N ogueira, esta última casa possuía

[...] a peculiaridade de ter construído, nos fundos, uma miniatura de todos os reinos em que se efetuavam os rituais, inclusive uma calunga pequena (cemitério) para ali realizar os trabal hos sem sair do local do Templo, preocupado com as deturpações já então existentes. (ibidem)

U ma particularidade desses templos mencionados, e que hoje já não mais vigora, reside no fato de que 
a abertura dos trabal hos era efetuada por uma linha que hoje não mais encontramos: a linha das Yaras que se apresentavam arrastando-se pelo chão, como o fariam as sereias em terra seca, e promoviam a limpeza do templo utilizando-se de água (idem).

No mais, na umbanda do Rio Grande do Sul são cultuados "caboclos", "pretos-velhos" e "crianças" (I beji), aos quais não são realizados sacrifícios de animai s. ${ }^{12} 0$ utrora era também cultuada a "linha", ou "povo do oriente", hoje quase em extinção. Segundo a representação dos umbandistas, tratavam-se de entidades bondosas, bastante evoluídas e que transmitiam vibrações puras. Seus médiuns, incorporados, adotavam a postura corporal e os gestos dos povos do O riente: chineses, indianos, árabes e ciganos. N os trabal hos da casa de Pernambuco N ogueira manifestavam-se duas entidades indianas: Brahmayana e $\mathrm{N}$ argajuna.

$\mathrm{H}$ oje o "povo cigano" foi transformado em Linha de Exu. Q uanto aos guias orientais, manifestam-se em poucas casas que trabal ham com o que denominam de Junta M édica.

\section{A Linha Cruzada}

Trata-se de uma expressão rel igiosa relativamente nova, iniciada, tudo indica, na década de 1960. Constitui, porém, a que mais tem crescido neste estado, sendo cultuada hoje em cerca de $80 \%$ dos terreiros. Segundo N orton Correa, esta modalidade ritual ística chama-se Cruzada

[...] porque, enquanto o Batuque cultua apenas orixás e a U mbanda caboclos e pretos-velhos, a Linha Cruzada reúne-os no mesmo templo, cultuando, al em deles, também os exus e suas mulheres míticas, as pombagiras, provavel menteoriginários da M acumba do Rio deJ aneiro eSão Paulo. (C orrea, 1998a:48)

Ainda segundo Correa, as principais razões para o crescimento da Linha C ruzada seriam os seguintes: os custos dos rituais são mais baratos do que os do batuque; o aprendizado geral é mais simples do queo do batuque; seus membros podem reunir esomar a força mística do batuque com a da umbanda (ibidem:90).

A proliferação de terreiros cruzados tem se constituído num forte motivo de polêmica e de acusação mútua entre os membros das religiões afro-brasileiras do RS. Trata-se, em verdade, de um conflito em parte intergeracional, em que os "mais velhos" na religião tendem a considerar essa inovação como uma "deturpação" da religião dosorixás por parte dos mais jovens, ao mesmo tempo em 
que expressa em parte também um conflito entre os "conservadores" eos "modernos", as mudanças sendo compreen didas pel os batuqueiros mais apegados à tradição como uma violação dosfundamentos da religião.

D e uma maneira geral, são extremamente precários os números acerca dos terreiros existentes no Rio G rande do Sul, bem como a incidência de rituais dentro das três modalidades religiosas acima referidas. Seja como for, e para dar ao menos uma idéia de grandeza, sugiro que deva existir hoje cerca de trinta mil terreiros em atuação ${ }^{14}$ neste estado, onde, em cerca de $80 \%$ deles são celebrados rituais de Linha Cruzada, em 10\% somente rituais de U mbanda (caboclos e pretos velhos) e em 10\% somente rituais de Batuque (nação).

N este estado, como já assinalou C orrea (1996), a estruturação das três diferentes expressões religiosas afro-brasilei ras acompanha, até certo ponto, as mudanças que atingiram a própria estrutura da sociedade.

D e fato, o batuque floresceu na segunda metade do século XIX eadaptou-seàs condições de um Rio G rande do Sul "tradicional", eminentemente agrário, pois naquela forma religiosa a tradição regia a estrutura ritual com os orixás formand o uma grande família patriarcal. O s sacrifícios de animais não ofereciam problemas num estado pastoril e em uma Porto Alegre onde havia ainda bairros "rurais". As iniciações podiam ser longas, pois as relações de trabalho eram ainda relativamente frouxas.

Jáa umbanda seinstal ou no RS na década de 30 num quadro social em que a implantação do capitalismo encontrava-se numa fase mais adiantada: a economia se monetarizava, iniciava-se 0 processo de industrialização, já ocorria o êxodo rural. 0 tempo tomava nova dimensão. As pessoas centravam suas vidas em tomo do trabalho. A umbanda se adequou aos novos tempos: seus rituais não se prolongavam noite adentro, não faziam uso de tambores e não realizavam sacrifíciosdeanimais. D essa forma, osfiéis podiam cumprir suas obrigações religiosas sem alterar o ritmo do cotidiano; não se prejudicava o sono dos vizinhos e se levava em conta a diminuição dos espaços para criar os animais que, além disso, se tornavam uma mercadoria cara.

A Linha C ruzada surgiu a partir da década de 60 numa fase de consolidação do capitalismo com o conseqüente incremento de graves problemas, tais como desemprego, insegurança, doenças, frustrações. $\mathrm{N}$ este contexto, a Linha C ruzada torna-se uma reli- 
gião prática, pragmática, de serviço, que se especial iza nas solu ções sobrenaturais daqueles problemas.

\section{O Príncipe Custódio de Almeida}

D etenho-meagora, mesmo que sucintamente, sobre um dos mais controvertidos personagens do campo afro-gaúcho, um príncipe africano, herdeiro do trono de Benin, que morou no Rio Grande do Sul de 1899, quando chegou à cidade de Rio G rande, até 1935, quando faleceu em Porto Alegre.

Segundo informações colhidas por $\mathrm{M}$ aria $\mathrm{H}$ elena $\mathrm{N}$ unes da Silvajunto a diferentes fontes - bibliográficas, intelectuai safricanos e, sobretudo, dois filhos biológicos de C ustódio - este descendia da tribo pré-colonial Benis, dinastia de G lefê, da nação J eje, do estado de Benin, na N igéria. Seu nome tribal era 0 suanlele 0 kizi Erupê, filho primogênito do O bá O vonramwen (Silva, 1999).

H á diferentes versões sobre sua saída da terra natal. Todas, porém, estão associadas à invasão britânica ao reino de Benin, em 1897, diante da qual não se sabe ao certo se 0 suanlele teria resi stido, ou fugido, ou, então, feito um acordo com os britânicos para deixar o país e viver no estrangeiro, onde receberia mensalmente uma pen são do governo inglês (a mais provável). D efato, D ionísio Almeida, filho de C ustódio, relatou a $\mathrm{M}$ aria $\mathrm{H}$ elena que seu pai teria deixado Benin em direção ao Porto de Ajudá, acompanhado por oficiais ingleses e por parte do seu Consel ho de $C$ hefes, onde teria permanecido por cerca de doismeses, dali embarcando para 0 B rasil, tendo chegado ao porto deR io G randeem 7 desetembro de 1899, com uma comitiva formada de 48 pessoas, em sua maioria membros do seu C onselho. Segundo aquele informante, antes de chegar a Rio G rande C ustódio teria estado em Salvador, depois no Rio de J aneiro, tendo se estabelecido em Rio G rande por orientação dos orixás, através dos ifás. ${ }^{15}$ C ustódio permaneceu nesta cidadeatéo dia 4 de outubro de 1900, quando se transferiu para Pelotas, eno dia 4 de abril de 1901 vei o para Porto Alegre, a convite do então presidente do estado, Julio de Castilhos, que al gumas semanas antes o teria procurado em Pelotas como último recurso para remediar um câncer quetomava conta de sua garganta. C omo teve uma melhora temporária, teria convidado Custódio a morar em Porto Alegre para continuar a tratá-Io nesta cidade, o que não im- 
pediu, porém, a morte deJ ulio de C astilhos aos 43 anos de idade, em 1903.

Em Porto Alegre, Custódio morou durante 35 anos na rua Lopo Gonçalves, na cidade baixa. $M$ antinha-se com a pensão mensal que recebia do governo inglês, via B anco do Brasil. Consta que se apresentava em público sempre bem vestido, desfilava pela cidade com uma carruagem puxada por parel has de caval os brancos e pretos, dedicava-se ao seu esporte preferido, o turfe, possuía um haras, era proprietário etreinador de cavalos de corrida, nunca se casara e vivia em situação poligâmica. "H aras" e "harem", sintetizam a vida do Príncipe C ustódio em Porto Alegre, disse-me um velho e bem informado batuqueiro.

Consta também que a partir do seu primeiro contato para finsterapêuticos com o presidenteda Província, este e outros políticos da época, emesmo o sucessor de ulio deC astilhos, Borges de M edeiros, bem como G etulio Vargas, teriam visitado o Príncipe em sua casa e este teria estado em várias oportunidades no palácio do governo. Esteé, porém, um tema controvertido, uma vez queà primeira vista parece difícil que aquel es políticos, fervorosos positivistas, procurassem o "feiticeiro" africano. M as não seria ilógico pensar que este nobre e político africano, durante os 35 anos de vida em Porto Al egre, não pudesse ter sido socialmente contatado pelos políticos ou por membros da elite local.

Também controvertido é o papel desempenhado por este Príncipe no que diz respeito aos membros da sua etnia. No campo político, enquanto por um lado diz-se que ele teria usado do seu prestígio para conquistar melhor espaço para os negros locais e contribuído para aliviar o preconceito e a discriminação que pesa sobre eles, por outro, recrimina-seque el eteria usado suas relações políticas unicamente em favor dos membros da sua família, empregando-os no serviço público, por exemplo, pouco ou nada fazendo para os negros em geral. $\mathrm{N}$ o campo religi oso paira a mesma controvérsia. Por um lado, muitos são os pais e as mães-de-santo de Porto Alegre que se dizem descendentes da linhagem religiosa do Príncipe, defendendo que ele teria contribuído decididamente para a estruturação do batuque na cidade, para o reconhecimento social do mesmo e para diminuir as perseguições policiais; mas, por outro lado, afirma-se também que ele não teria iniciado ninguém, poissendo nobrenão teria "posto sua mão" em nenhum plebeu, e que teria atuado como religioso somente para as elites e as pessoas de sua amizade e família. 
Seja como for, segundo consta na sua certidão deóbito, C ustódio morreu em 28 de maio de 1935, aos 104 anos, solteiro edeixando bens. Sua mortefoi noticiada nosjornaislocaise seu enterro foi bastante concorrido, contando inclusivecom a participação de políticos da época.

H oje o Príncipe C ustódio constitui um mito no imaginário negro do Rio Grande Sul e, como escreveu N . Correa, "a figura ainda hoje mais legendária que a memória dos integrantes do Batuque guardam [...]" (C orrea, 198a:77). N o entanto, quanto à sua vida e realizações, e às várias controvérsias que as envolvem, trata-se de mais um tema à espera de pesquisadores que efetuem uma investigação transatlântica.

Os Brancos nas Religiões Afro-Brasileiras do Rio Grande do Sul

O Rio G rande do Sul é uma sociedade multiétnica e pluricultural construída no "encontro de civilizações", como diria Bastide, onde os nativosindígenas viram seu território sendo ocupado pelos portugueses eespanhóis, aos quaisforam associados os escravos africanose, posteriormente, os imigrantes europeus, com destaque para os alemães e os italianos. ${ }^{16}$

Em termos gerais, hoje a composição multiétnica do Rio Grande do Sul é assim constituída: $86,8 \%$ são brancos, 4,1\% negros, $8,9 \%$ pardos e $0,2 \%$ indígenas (PN AD, IBGE, 1999). Com estes números, o R io G rande do Sul constitui o estado mais "branCo" do Brasil, depois de Santa C atarina. ${ }^{17}$

O ra, neste território multiétnico, malgrado a posição superior que os brancos ocuparam em relação aos negros e aos índios, ocorreram, de alguma forma, trocas culturais em diferentes direções, sendo uma delas a aproximação dosnão-brancos, dediferentes etnias e de diferentes camadas sociais, às religiões afrobrasileiras.

É praticamente impossível saber quando este encontro começou a ocorrer. Tudo indica, porém, que data ainda do século $X I X$, tendo aumentado nas primeiras décadas do século XX e se consolidado a partir da segunda metade daquele século, quando, então, há notícias de brancos que ocupam a condição de pais e mães-de-santo. Estefenômeno, como se sabe, ocorreu em praticamente todo o B rasil, chegando ao ponto em que hoje, em algumas regiões, como escreve Prandi, referindo-se a São Paulo, "o C an- 
domblé é uma religião que não pode ser caracterizada como uma religião de negros" (Prandi \& Silva, 1987:4). Trata-se, antes, de religiões multiétnicas e universais (Prandi, 1991).

A procura de terreiros por parte dos brancos pobres geralmente está associada à busca de solução para problemas práticos como doenças, desemprego ou dificuldade econômica, ou problemas legais, geralmenterelacionadosà sua condição desfavorável de classe. Já os brancos de maior poder aquisitivo o fazem na busca de solução de problemas existenciais como os de sentido, identidade, afetivos, etc. Também o caráter misterioso, exótico efascinante da religião dos orixás, associado à sua eficácia simbólica, contribui para a atração de brancos.

D iga-se de passagem que as mesmas ou semelhantes razões apontadas para a aproximação dos brancos das camadas populares aos terreiros servem também para os negros ingressarem neles. N o entanto, não se pode imaginar uma convivência harmônica entre negros e brancos nos terrei ros multiétnicos gaúchos. 0 corre aqui uma espécie de tolerância mútua ou, como Silva e Amaral referiram para São Paulo, uma

espécie de negociação velada on de os brancos, com dinheiro, tornam-se necessários à própria sobrevivência do terreiro de maioria negra e, assim, o queévisto como negativo (a entrada dosbrancos no candomblé) acaba adquirindo sinal positivo, já que a concessão é necessária à manuten ção das despesas da casa. (Silva \& Amaral, 1994:17)

Em outras palavras, parece prevalecer no Rio G rande do Sul a representação negra segundo a qual é importante a presença simultânea de brancos e de negros nos terreiros por serem, os primeiros, detentores principalmente de capital econômico e os segundos principalmente de capital simbólico, religioso, dado pela tradição. Evidentemente que os atores sociais implicados no processo nem sempre possuem esta consciência dos fatos. É mais recorrente neles a afirmação de que "o axé não tem cor".

$\mathrm{N}$ o entanto, há terreiros multiétnicos ondeo preconceito de cor tende a se manter. I sto se dá especialmente quando os brancos implicados na religi ão detêm pouca consciência da origem africana desta e não realizam uma aproximação mais efetiva com a etnia negra. Há outros terreiros multiétnicos, porém, onde até certo ponto e por um tempo limitado parece haver uma suspensão dos preconceitos raciais; neste caso, negros ebrancos juntam-se no espaço religioso para se divertir, rezar efortalecer uma identidadesocial comum. 
O s terreiros multiétnicos a que me refiro reúnem especialmente pessoas das camadas populares. Isto porque os terreiros de camadas médias tendem a ser predominantemente freqüentados por brancos, en quanto os terrei ros de camadas al tas são freqüentados quase que exclusivamente por brancos. Em todos eles, como mostrei em outro lugar (O ro, 1998), são reproduzidas as desigualdades raciais encontradas na sociedade gaúcha (e brasileira).

\section{A Expansão das R eligiões Afro-Brasileiras para os Países do Prata}

U m outro aspecto que sobressai no estudo do atual campo religioso afro-gaúcho consiste na importância que ele tem para o ressurgimento e introdução das expressões religiosas de matriz africana nos países do Prata. Com efeito, a Argentina já teve uma história de reprodução dessas religiões até o final do século XIX, quando os atabaques, tocados até então pela comunidade afro-argentina, silenciaram em razão do abrupto declínio desta população. ${ }^{18}$ Já no U ruguai, não consta ter havido uma histórica prática rel igiosa africana, mas importantes expressões musicais de origem africana como o candombe. ${ }^{19} \mathrm{~N}$ o entanto, em ambos os países, a partir da década de 60 do século passado, verifica-se o reingresso (na Argentina) ea introdução (no U ruguai) das religiões de matriz africana, sobretudo através do Rio G rande do Sul.

Este processo ocorreu primeiramente nas cidades platinas fronteiriças com o Rio G rande do Sul edali alcançaram as capitais federais. D eveu-se a iniciativas que partiram de ambos os lados da fronteira, ou seja, de pais e mães-de-santo brasileiros que procederam à expansão da religião para os países platinos e de cidadãos desses países que procuraram terreiros brasileiros.

$\mathrm{N}$ a década de 70, o fluxo se estendeu até Porto Alegre, onde se local izava o maior número de renomados batuqueiros que passaram a ser visitados por argentinos euruguaios. Estes para aqui vinham em busca de iniciação religiosa junto a um famoso pai ou mãe-de-santo, ao mesmo tempo em que buscavam o reconhecimento oficial da sua condição de iniciados, ou sacerdotes, junto a uma federação local. Sem tais documentos, tinham muitas dificuldades de praticar a religião em seus países, sobretudo na Argentina, podendo até mesmo sofrer perseguições policiais.

0 período áureo das relações religiosas internacionais platinas ocorreu na década de 80. Em relação à A rgentina deu-se sobre- 
tudo após o retorno à vida democrática, em 1983 (Frigerio \& C arozzi, 1993), enquanto no U ruguai o crescimento do número de terreiros eo incremento das relações religiosas com o B rasil coincidiram com o período ditatorial, que se estendeu até 1985 (H ugarte, 1993).

$N$ a década de 90 ocorreu um arrefecimento das relações religiosas entre gaúchos e platinos eisto se deveu, segundo o discurso dos pais e mães gaúchos, à crise econômica que se abateu sobre aqueles países, sobretudo na Argentina, que reduziu os investimentos das pessoas na religião, embora não tenha diminuído o interesse pela mesma. M as há um não-dito: 0 arrefecimento também se deveu à concorrência religiosa que estão sofrendo naqueles países. 0 u seja, se atéo início da década de 90 havia uma rel ação relativamente assimétrica, mas aceitável, entre os pais e mães gaúchos e seus filhos platinos - os primeiros colocando-se numa posição hierárquica superior - a partir deste período estabeleceu-se uma relação conflituosa entreal guns, senão a maioria dos pais-de-santo gaúchos (cerca de 15 pessoas), que participam do circuito religioso platino, sobretudo argentino, e os seus colegas deste país, posto que estes últimos passaram a disputar poder pela ocupação do espaço religioso afro-brasileiro e pelo exercício legítimo do sacerdócio naquele país.

Apesar disto, nos dias atuais continuam as viagen s de membros das religiões afro-brasileiras nos diferentes sentidos e foram criadas verdadeiras redes internacionais de parentesco simbólico, as quais constituem denominadores de frontei ras sociais esimbólicas que contribuem para a construção de verdadeiras identidades transnacionais. Ao mesmo tempo, essas redes constituem umaforma de integração regional/internacional, legitimada religiosamente, mediatizada pelas religiões afro-brasileiras, onde a nacionalidade eas diferen ças sociais e ideológicas não são anuladas, mas superpostas à religiosa.

Evidentemente que a construção de identidades não significa a formação de comunidades (no sentido tradicional do termo) internacionais. I gual mente, a integração e a formação internacionais de redes de famílias-de-santo não significa que as relações entreos seus membros sejam harmônicas. Elas continuam a reproduzir o ethos de rivalidade e al iança que caracteriza o campo religioso afro-brasileiro. ${ }^{20}$ 
As R eligiões Afro-Brasileiras no Rio Grande do Sul e suas Relações com o Poder Político Local

$\mathrm{N}$ os últimos anos, as religiões afro-brasileiras parecem ter conseguido, em Porto Alegre, uma aproximação não al cançada até então, e em nenhum outro local do estado, com o poder público local. É sobretudo nas gestões do PT na prefeitura, especialmente na segunda e na atual, em que o chefe do Executivo éT arso G en$\mathrm{ro}^{21}$ queaquelas religiões conseguem lograr apoios einteragir diretamente com o gabinete do Prefeito e com al gumas secretarias, como da Cultura e do M eio Ambiente, tudo isto ocorrendo, porém, não sem conflitos. ${ }^{22}$

Assim, em Porto Alegre, mediante Lei M unicipal, e por intermediação da Secretaria M unicipal da C ultura e da C âmara M unicipal dePorto Alegre, desdeo ano de 1996 comemora-sea Semana da U mbanda e dos Cultos Afro-Brasileiros. O s eventos desta Semana são compostos de pal estras e rituais, cel ebrados no Parque da $\mathrm{H}$ armonia, no centro da cidade. Iniciam-se no dia 15 de novembro com uma sessão de U mbanda e encerram-se em 20 de novembro, D ia $\mathrm{N}$ acional da Consciência $\mathrm{N}$ egra, com uma sessão de Batuque. $N$ estes eventos comparecem autoridades civis, membros das religiões afro-brasileiras, além de simpatizantes, curiosos e 0 povo em geral.

0 utra atividade pública semelhante a essa, e que também consta como Lei M unicipal dePorto Alegre, éaF esta da 0 xum, celebrada desde 1996 em todos os dias 8 de dezembro, na praia de Itapema, diante da imagem deste orixá erguida à beira do Rio Guaíba. N esta ocasião ocorre também uma sessão religiosa na praia em homenagem à deusa das águas doces.

É digno de nota que ambas as atividades referidas, a Semana da U mbanda ea F esta da 0 xum, constam no cal endário deeventos da prefeitura de Porto Alegre.

O utra iniciativa de parceria com o poder público ocorreu entre as três maiores federações do estado (C onselho Superior da U mbanda e dos Cultos Afro-brasileiros, Afrobras e Aliança U mbandista e Africanista do Estado) e as Secretarias Estadual e M unicipal do $M$ eio Ambiente, ao editarem um caderno de orientação intitulado "A Educação Ambiental eas Práticas das R eligiões Afro-U mbandistas", com o objetivo de "orientar as C asas de Religião e funcionários do poder público municipal e estadual sobre procedimentos em relação a cultos e colocação de trabal hos religiososno meio ambiente". Trata-sedeum manual deaconsel hamen- 
tos em relação às oferendas, tendo como pressuposto a preservação da natureza.

As federações acima mencionadas também conseguiram, junto ao poder público municipal e à Assembléia Legislativa do estado, o apoio financei ro elogístico para real izar anual mente um Seminário Cultural e Teológico da U mbanda e dos Cultos Afro-B rasileiros do Estado do Rio G rande do Sul. Trata-se de um seminário que desde a sua primeira edição, em 1996, é celebrado no salão nobredaAssembléia L egislativa do estado e conta com palestrantes oriundos do próprio campo religioso em questão e de pesquisadores dos mencionados cultos, provenientes de diferentes regiões do Brasil e dos países do Prata. 0 seminário tem duração de três dias e dele participam em média 400 pessoas.

Principalmente neste evento, mas também nos demais referidos, nota-se semprea presença de políticos, dos Executivos e Le gislativos, municipal e estadual, de distintos partidos.

O utra forma de aproximação do campo religioso afro-brasileiro com o político ocorre através de outorga de comendas e títul os honoríficos, com que os governos locais distinguem alguns líderes destas religiões. Assim, por exemplo, o babalorixá Cleon (Fonseca) de 0 xalá recebeu das mãos do então governador do Estado do Rio G rande do Sul, Antônio Brito, em 30/6/1996, a medalha N egrinho do Pastoreio, a mais alta comenda do estado. Três pais-de-santo receberam na C âmara M unicipal de Porto Alegre o título de cidadãos de Porto Alegre. São eles: Ailton (Albuquerque) da 0 xum, Jorge (V erardi) deX angô eAdalberto Pernambuco Nogueira - o primeiro nascido em Pelotas (RS), em 3/11/1945, o segundo em C ruz Alta (RS), em 19/10/1949, eo terceiro em Belém do Pará, em 3/11/1928.

0 último agraciado, Adalberto Pernambuco Nogueira, é presidente do Conselho Estadual da U mbanda e dos Cultos Afro-Brasileiros do Rio G rande do Sul (CEU CAB/RS), euma das maiores lideranças desta religião no estado. D evido o seu carisma e bom trânsito na esfera pública, tem contribuído para as religiões afro-brasileiras conquistarem maior e melhor espaço tanto no campo político quanto no campo religioso institucional. $\mathrm{N}$ a área política tem participado, enquanto representante das religiões afro-brasileiras, no Conselho Político de Campanha da F rente Popular (formado então por cerca de 160 pessoas de destaque das várias áreas de atuação social e profissional) por ocasião das últimas eleições municipais de 2000, eatual menteintegra o Conselho Político de Governo da Frente Popular (formado por cerca de 300 
pessoas). I gualmente, a partir de janeiro deste ano foi escolhido como membro do Consel ho M unicipal de Cultura.

Além destas atividades no meio político, Pernambuco N ogueira é o representante mais solicitado das religiões afro-brasileiras por ocasião de cel ebrações ecumênicas, ocorridas, por exemplo, por ocasião das posses do governador do estado edo prefeito municipal, no dia do aniversário da cidade de Porto Alegre(26 demarço), no dia das M ães ena celebração de 25 de agosto, dia de São Cristóvão, padroeiro dos motoristas.

Em tais cultos ecumênicos comparecem representantes da igreja católica, da igreja luterana, do islamismo, do budismo, do judaísmo, do espiritismo, além dos cultos afros.

$M$ as, se, de um lado todos os fatos acima mencionados revelam uma aproximação - que, como já disse, não ocorre sem tensões - entre as religiões afro-brasileiras e o poder político no Rio G rande do Sul, por outro lado, os representantes dessas religiões não logram ingressar di retamente no campo político mediante a condução pelo voto. O u seja, malgrado as tentativas para sua viabilização de parte de alguns renomados pais, não conseguiram eleger nenhum seu representante nas $C$ âmaras $M$ unicipais e muito menos na Assembléia L egislativa do estado. 0 único precedenteneste sentido data da década de 1960, quando o umbandista M oab Caldasfoi eleito paraa Assembléia L egislativa do estado, pelo PT B de Leonel Brizola e Jango G oulart, e reeleito nos anos de 1964 e 1968. Foi cassado em 1968, vindo a falecer em 1997. ${ }^{23}$ Também no ano de 1960 foram eleitos 3 prefeitos e cerca de 20 vereadores umbandistas no Rio G rande do Sul.

Após este período não parece ter havido mais presença efetiva de membros desta religião em cargos eletivos no Rio G rande do Sul, malgrado algumas tentativas, como a do babalorixá Ailton Albuquerque, de Porto Alegre, que se apresentou às eleições legislativas gaúchas nas últimas el eições de 1998 pelo Partido TrabaIhista B rasileiro (PT B). N ão logrou se el eger, tendo obtido 3.425 votos, quando o mínimo necessário situa-se em torno de dez mil, dependendo da situação da legenda.

$N$ as eleições de 2000 não consta ter havido algum líder desta religião quetenha sido eleito em al gum município do R io G rande do Sul. Em Porto Alegre, entre os 411 candidatos a vereador para a Câmara M unicipal, havia 5 representantes das religiões afrobrasileiras, 4 pais-de-santo e 1 presidente de um famoso terreiro. Foi, entre el es, o presidente da F ederação Afrobras quem obteve 0 maior número de votos, 1.994, este montante representando, po- 
rém, somente um quarto dos votos necessários para ser el eito. O s demaiscandidatos obtiveram 1.668, 1.109, 451 e 421 votos, totalizando, juntos, 5.643 votos, quantia insuficiente para eleger um único candidato. ${ }^{24}$

0 discurso eleitoral veiculado pelos pais-de-santo de Porto Alegre para dentro da "comunidade" afro-umbandista era fundamentalmente o mesmo: a necessidade de a "religião" ter representantes no legislativo municipal para defender os seus direitos e para mostrar sua força perantea sociedadee, sobretudo, perante os evangélicos (pentecostais), que estão ampliando seu espaço na política e se mostrando abertamente críticos em relação às religiões afro-brasileiras. 0 ra, este discurso não produziu a eficácia esperada pelos candidatos e, a meu ver, isto se deve, sobretudo, à própria estrutura e ao ethos das religiões afro-brasileiras.

De fato, o modelo organizacional das religiões afro-brasileiras repousa sobre uma variedade de federações e uma pulverização de terreiros, sendo todos ao mesmo tempo autônomos e rivais entre si. Como não existe, no âmbito desta religião, umaúnica hierarquia religiosa, um poder centralizador eagl utinador dos centros religiosos, estes constituem-se autônomos e, por isso mesmo, concorrentes entre si. Em conseqüência disso, reconhece 0 candidato a vereador Jorge Verardi, presidente da Afrobras, "cada um procura sua própria autopromoção". "N ão temosa organização dos al eluia”, disse uma mãe-de-santo.

0 ra, este ethos constituído de permanente disputa, rivalidadeentreterreirose desqualificação do outro, torna, como reconheceR. Prandi, bastante remota a possibilidade de união entreterreiros e grupos, mesmo em se tratando de proveito para a religião (Prandi, 1991:163). ${ }^{25}$

\section{Considerações Finais}

Malgrado os avanços alcançados nos últimos anos pelas ciências sociais ehumanas na compreensão da história e do presente do negro e sua cultura no R io G rande do Sul, muita coisa ainda resta a ser investigada.

Talvez não pese hoje tão forte como há alguns anos atrás a frase escrita em 1940 pel o historiador D . de Laytano quando afirmava que "osnossos cronistas, os historiadores de compên dios oficiais e toda a literatura gaúcha não se ocuparam do negro senão acidental, ligeira e negligentemente" (Laytano, 1940). N o entan- 
to, mal grado produções recentes, permanece atual a exortação de outro historiador, M ário M aestri Filho: "ahistória do escravo sulino, proto-história do proletariado gaúcho, ainda está por escrever-se" (M aestri Filho, 1979:67). Especificamente sobre as origens do negro gaúcho, escreveu que "não sabemos rigorosamente nada" (idem, 1993:30), enquanto $\mathrm{N}$ orton Correa afirmou que "ainda não foram perfeitamente esclarecidas as origens das populações trazidas como escravos para o Rio G rande do Sul" (C orrea, 1998a).

A explicação para a desconsideração do negro pela academia, mas não só ela, pode residir, como salienta R. O liven, no próprio processo de construção política e cultural do R io G rande do Sul, onde ocorreu um interesse massivo e concentrado em torno da figura do gaúcho - quefoi el evado à condição de "autêntico" representante desse território - e do colonizador europeu, em detrimento deoutros grupos sociais aqui presentes desdeo princípio da colonização, como os negros e os índios. Estes parecem condenados ao silêncio eao esquecimento e comparecem no âmbito das representações de uma forma extremamente pálida. Particularmente quanto ao negro prevalece uma invisibilidade social e simbólica (O liven, 1996) ao mesmo tempo em queainda predomina, no Rio Grande do Sul, a auto-imagem de um estado branco e moderno, construído pelas figuras "heróicas" dos gaúchos e dos imigrantes europeus e seus descendentes.

N o contexto de exclusão do negro esua cultura no Rio G rande do Sul figura também o batuque, cuja história, linhagens, tradições religiosas e repressão policial, permanecem ainda com lacunas, incógnitas e dúvidas não resolvidas, como pudemos constatar neste trabalho.

$\mathrm{N}$ otas

1. Por setratar deum texto que pretendeser, atécerto ponto, um vôo panorâmico sobre as rel igiões afro-brasileiras no R io G randedo Sul, este será, necessariamente, superficial em alguns aspectos; porém, essa deficiência poderá ser em parte sanada com as indicações bibliográficas respectivas para os interessados.

2. O u seja, atuaram como mão-de-obra nos engenhos de açúcar de Pernambuco e Bahia, na mineração aurífera de $M$ inas $G$ erais, nos campos de fumo e cacau da Bahia e Sergipe, no cultivo do cafédo Rio deJ aneiro e São Paulo, no algodão do $M$ aranhão e Pará, nas plantações decafétambém cultivado no Espírito Santo, na agricultura epecuária do Rio Grande do Sul e na mineração de G oiás e M ato G rosso. 
3. Sabe-se que durante al gum tempo o envio para o Sul era tido como um pesado castigo e forteameaça aos escravos desobedientes, por parte dos patrões de outras regiões do Brasil.

4. D e fato, ao efetuar uma comparação entre o candomblé da Bahia e o batuque o Rio Grande do Sul, H erskovits propunha a hipótese de que a existência do africanismo no Rio G rande do Sul resulta de um trabalho independente eparal elo, "de idênticos impulsos culturais africanos primitivos". Ponderava, porém, de que tal hipótese deveria ser revista com os avanços dos estudos historiográficos "sobre a migração negra dentro do Brasil e da procedência tribal africana dos negros importados para a parte sul do país" (H erskovits, 1948:64).

5. “Embora ocupada desde os meados do século XVIII por colonos açorianos, Porto Alegresó começou a se desenhar após 1772, quando sedeu a primeira demarcação do espaço urbano e a distribuição de datas de terras para esses açorianos. Só então a condição de ponto estratégico daquele sítio vai transfigurar-se em funções comerciais e político-militares" (K ersting, 1998:61). A instalação de Porto Alegre como capital da província ocorre em 1773. Sua população era de 1.500 habitantes em 1780 e 12.000 em 1820.

6. “Era uma região insalubre, fora do centro urbano, habitada por uma população pobre, essencialmente negra, estigmatizada pelos órgãos oficiais, pela imprensa e por tudo aquilo que era considerado soci edadena época" (K ersting, 1998:148). A pal avra "Areal" tem sentido ambíguo. Trata-se de uma corruptela da palavra Arraial, mas também área de depósito de areia do fluxo da foz do riacho I piranga com o rio G uaíba. A palavra "B aronesa" refere-se à proprietária dessa chácara, de então, a B aronesa do G ravataí.

7. “Como limites mais ou menos definidos da C olônia Africana, podemosestabelecer a RuaR amiro Barcel os, a Avenida Protásio Alves (antigo C aminho do M eio) atéa al tura da $R$ ua $D$ ona L eonor, seguindo pela parte al ta até aproximadamente 0 atual I nstituto Porto Alegre (IPA), e deste atéa rua C astro Alves, descendo por essa atéa Ramiro Barcelos, de onde partimos" (Kersting, 1998:102).

8. 0 número de moradores dessas áreas não é preciso. Relativamente à Colônia Africana, era de 3.460 em 1910; 4.299 em 1912 e 5.636 em 1917. Estes números correspondem respectivamente a 2,66\%, 2,92\% e 3,15\% do total da população de Porto Alegre nesses anos (K ersting, 1998:128-129).

9. Este autor mostra como a análise dos registros de ocorrências policiais da virada do século em relação à C olônia Africana não são superiores às de outras áreas da cidade, mesmo o centro, considerado "civilizado" e "moderno". Entretanto, sobre este não foram construídas representações sociais excludentes como em relação àquel e território negro da cidade (K ersting, 1998).

10. A expulsão se dá mediante a expansão da cidade com a conseqüente valorização da área, que implica em aumento de impostos, impossível de ser pago por moradores de baixa renda.

11. São os seguintes os principais orixás cultuados no batuque: Bará, 0 gum, 0 iá, Xangô, $O$ dé ( $O$ tim), $O$ ssanha, $O$ bá, Xapanã, Bêdji, 0 xum, I emanjá e $O$ xalá. 0 anexo I apresenta um conjunto de elementos vinculados a cada um desses orixás, segundo a tradição batuqueira gaúcha. 
Religiões Afro-Brasileiras do Rio G rande do Sul: Passado ePresente

12. Segundo Paulo Tadeu B. Ferreira, na N ação C abinda, por exemplo, a língua ritualística deveria ser o Bantu (Kunbundo) eos deuses chamados de Inkices. $\mathrm{N}$ a prática cultuam-se os orixás em lingua yorubana. $\mathrm{N}$ a $\mathrm{N}$ ação J eje (J eje), a língua deveria ser 0 Ewe e os deuses os voduns. $\mathrm{N}$ a prática adotam o mesmo procedimento da $\mathrm{C}$ abinda, que é o mesmo do ljexá e do 0 yó (F erreira,1997:42).

13. 0 anexo II apresenta algumas especificações das entidades acima mencionadas.

14. 0 anexo III apresenta os nomes e al gumas concepções relativas às principais entidades da Linha Cruzada praticada no Rio G rande do Sul.

15. Este montante é aproximado, mesmo porque "terreiro" é uma categoria ampla que reúnedesdeum congáfamiliar onde seu dono recebeclientes para "jogar", atéum espaço onde são realizados rituais de distintas expressões religiosas afro-brasil leiras no âmbito de uma comunidade religiosa local. Seja como for, mesmo os terrei ros no Rio Grande do Sul, segundo esta última observação, podem ser considerados de tamanho pequeno ou médio, pois o número médio de freqüentadores situa-se entre $10 \mathrm{e}$ 30 pessoas, sendo reduzidos os terreiros que reúnam num único espaço ritualístico em torno de 100 pessoas.

16. Eis, textualmente, o depoimento de Dionísio:

“[...] o F ortedeSão J oão Batista de Ajudá era comandado por um baiano, o qual tornou-seamigo do papai eindicou-Ihea Bahia como lugar adequado paraviver no Brasil. I sto porqueJ oséM aria só conhecia a Bahia, nada saben do dos outrosestados brasil eiros. Q uando 0 suanlele chegou à Bahia el e jogou novamente seus ifás e, em resposta, obteve que ainda não era aquele lugar o escolhido. D a Bahia ele foi para o R io deJ aneiro. C onheceu al gumas pessoas que professavam a religião africana. $B$ em, na Bahia ele também conheceu importantes figuras que estavam ligadas diretamente à religião africana. Lembro que ele nos dizia que tinha muitas coisas que ele entendia sobre a sua religião. H omenagens foram feitas a ele" (D ionísio, 13/5/1988 apud Silva, 1999:71).

17. D e fato, os al emães desembarcaram no Rio G rande do Sul a partir de 1824, tendo chegado a mais de 60.000 indivíduos até 1939. 0 s imigrantes ital ianos, por sua vez, chegaram a partir de 1875 ea última vaga desembarcou em 1914. N este período, entre 70.000 e 100.000 italianos se estabeleceram no Rio G rande do Sul.

18. Segundo a mesma fonte, a distribuição étnica de Santa $C$ atarinaéde $91,0 \%$ debranCos, 2,1\% de pretos, $6,4 \%$ de pardos e $0,5 \%$ são índios (PN AD , IBGE, 1999).

19. 0 último depoimento sobre um ritual religioso de tipo afro-americano em Buenos Aires éde 1903 (Segato, 1991). Ainda segundo esta autora, a população negra era de $30 \%$ em Buenos Aires no início do século passado e caiu para $2 \%$ no final do mesmo século. As causas mais importantes do desaparecimento dessa população foram as guerras e as pestes. É possível também que seus últimos componentes tenham emigrado para o Sul do Brasil. Rita Segato aponta, no entanto, que o desaparecimento do negro na Argentina foi antesideológico, cultural eliterariamente construído, do que propriamente físico. 0 u seja, na imagem que os políticos e os intelectuais argentinos se fizeram de nação homogênea e depurada não havia lugar para o negro (id. ibid.).

20. Para uma análise sobre o candombe uruguaio ver Ferreira (1997). 
21. Para uma análise mais aprofundada do processo de transnacionalização das religiões afro-brasileiras do Rio G rande do Sul para os países platinos ver O ro (1999).

22. 0 PT estáno coman do da prefeitura dePorto Alegrehá 12 anos, tendo sido prefeitos O lívio D utra (1989-1992), Tarso G enro (1993-1996), Raul Pont (1997-2000) e Tarso G enro (2001-2004).

23. Talvez o conflito maior resida na própria administração municipal e, sobretudo, no interior do PT, onde vozes do partido, movidas por brios ideológicos, se erguem em desaprovação às relações estabelecidas pel os organismos executivos com as religiões afro-brasileiras e, mesmo, com as religiões em geral.

24. Diana Brown recorda que em 1960 os umbandistas também elegeram para a Assembléia Legislativa do Rio de aneiro A tila $\mathrm{N}$ unes - um radial ista umbandista que haviasido eleito vereador em 1958 (Brown, 1985). M ariaH elenaV illas-Boas Concone e Lísias $\mathrm{N}$ ogueira $\mathrm{N}$ egrão fazem uma análise histórica dos distintos momentos da relação da umbanda com a política e o estado, onde preval eceu a perseguição até o golpe de 1964 ea sua cooptação política a partir de então. M ais especificamente analisam o envolvimento político-partidário da umbanda paulista nas el eições de 1982 e anal isam a derrota dos candidatos umbandistas (C oncone e N egrão, 1985).

25. No entanto, não estamos emitindo nenhum juízo de valor sobre este permanente conflito entre líderes de terrei ros das religiões afro-brasileiras. $\mathrm{H}$ á mesmo alguns autores, como N . Correa que, baseado em G. Simmel, levanta a hipótese de que o conflito referido não representa algo negativo na vida social dessas religiões, posto que ele constitui a chave para explicar a permanência histórica e o crescimento das religiões afro-brasil eiras, em razão do seu papel também construtivo eagregador em termos sociais (C orrea, 1998b).

\section{Referências Bibliográficas}

ASSU M PÇÃO , J orge Euzébio (1990). "Idade, Sexo, O cupação e N acionalidade dos Escravos Charqueadores (1780-1888)". Estudos I bero-Americanos, vol. XVI, pp. 29-43.

BASTIDE, Roger (1959). A Sociologia do F olclore Brasileiro. São Paulo, Ed. Anhembi.

BRO W N , Diana (1985). “U ma H istória da U mbandano Rio". Cadernosdo I SER, no 18, pp. 9-42.

CON CONE, M aria Helena Villas-Boas \& NEGRÃO, Lísias Nogueira (1985). "U mbanda: D a Repressão à Cooptação. 0 Envolvimento Político-Partidário da U mbanda Paulista nas Eleições de 1982". Cadernos do ISER, no 18, pp. $43-79$.

CORREA, N orton Figueiredo (1996). "'A C ozinhaéa Baseda Religião': A Culinária Ritual no Batuque do Rio Grande do Sul". H orizontesAntropológicos, no 4, pp. 49-60.

— (1998a). Os Vivos, os M ortos e os D euses. Porto Alegre, dissertação de mestrado, PPGAS/UFRGS.

_ (1998b). Sob o Signo da Ameaça: Conflito, Poder e Feitiço nas Religiões Afro-Brasileiras. São Paulo, tese de doutorado em Antropologia, PU C/SP.

FER REIRA, Paulo Tadeu Barbosa (1997). O rixá Bará. N ação Religi osa de Cabinda. Porto Alegre, Editora Toquí. 
(1994). O sF undamentos Religiosos da N ação dos O rixás. (2ª ed.). Porto Alegre, Editora Toquí.

FERREIRA, Luís (1997). Los Tambores del Candombe. M ontevidéu, Ediciones Colihue-Sepé.

FRIGERIO, Alejandro \& CAROZZI, Maria Julia (1993). “Las Religiones Afro-Brasileñas en Argentina". Cadernos de Antropologia., no 10, pp. 39-68, Porto Alegre, UFRGS.

HERSK OVITS, M elville J. (1948). "D euses Africanos em Porto Alegre". Província de São Pedro, no 11, pp. 63-70.

IBGE (2000). Pesquisa N aci onal por Amostra deD omicílios 1999: M icrodados, Rio de aneiro, IBGE.

ISAIA, Artur C esar (1997). "O sPrimórdios da U mbanda no Rio G rande do Sul". Teocomunicação, vol. 27, no 117, pp. 381-394.

JEN SEN , T ina G rudrun (2000). “D iscursos sobre as R eligiões Afro-Brasileiras: D a D esafricanização para a R eafricanização". REVER, site www.pucsp.br/rever/

KERST IN G , Eduardo H . de O . (1998). N egros ea M odernidade U rbana em Porto Alegre: A C olônia Africana (1890-1920). D issertação de M estrado em H istória, Programa de Pós-graduação em H istória, U FRGS.

KREBS, C arlos G alvão (1988). Estudos de Batuque. Porto Alegre, Instituto G aúcho de Tradição e Folclore.

LAYT AN O , D antede(s/d). A I greja eos O rixás. Porto Alegre. E dição da C omissão G aúcha de Folclore, vol. 29.

_ (1987). Folclore do Rio Grande do Sul. (2ed.). Porto Alegre, Ed. N ova Dimensão/EST.

_ (1940). "O N egro e o Espírito G uerreiro nas O rigens do Rio Grande do Sul". In: A. Ramos(org.), 0 N egronoBrasil. Rio deJ aneiro, Civilização Brasileira, pp. 247-274.

M ELLO, M arco Antônio Lírio de (1994). Reviras, Batuques e Carnavais. A Cultura de Resistência dos Escravos em Pelotas. Pelotas, U FPel, Editora U niversitária.

LO N ER, Beatriz Ana (1999). "N egros: O rganização eL uta em Pelotas". H istória em Revista., no 5, pp. 7-28, U FPel.

M AEST RI FILH O , M ário (1993). 0 Escravo G aúcho: Resistência eT rabalho. Porto Alegre, Ed. da U niversidade.

_ (1979). Q uilombose Q uilombolas em Terras G aúchas. Porto Alegre, EST /U CS.

M AT O RY, J. Lorand (1999). "J eje: Repensando N ações e T ransnacionalismo". M ana, vol. 5, no 1, pp. 57-80.

N O GU EIRA, Adal berto Pernambuco (2001a). A U mbanda G aúcha. Porto Alegre (inédito).

_ (2001b). AsReligi ões Africanas no Rio Grande do Sul (Batuque). Porto Alegre (inédito).

SILVA, M aria Helena N unes da (1999). O "Príncipe" Custódio e a "Religião" Afro-G aúcha. Recife, dissertação de mestrado em Antropologia, UFPe.

O LIVEN, Ruben G eorge (1996). “A Invisibilidade Social e Simbólica do N egro no Rio G randedo Sul". In:I. B. Leite(org), N egrosno Sul do Brasil:I nvisibilidadeeT erritorialidade. Florianópolis, Letras Contemporâneas, pp. 13-32. 
Ari Oro

O RO , Ari Pedro (1999). AxéM ercosul. AsReligiões Afro-BrasileirasnosPaísesdo Prata. Pe trópolis, Vozes.

_ (1998). "As Relações Raciais nos Terreiros do Rio Grande do Sul". Estudos Afro-Asiáticos, no 33, pp. 31-50.

PI H U GARTE, Renzo (1993). "Las Religiones Afro-Brasileñas en el U ruguay". Cadernos de Antropologia, no 10, pp. 69-80. PPGAS/U FRGS.

PRAN DI, Reginaldo (1991). O sCandomblés de São Paulo. São Paulo, H ucitec-Edusp.

PRAN D I, R eginaldo \& SILVA, V agner G . (1987). Reafricanização do C andombléem São Paulo. Encontro Anual da Anpocs, Águas de São Pedro (SP).

SCH W ARCZ, Lília M oritz (1989). Retrato em Branco eP reto. Jornais, Cidadãose Escravos. Século XIX. São Paulo, C ompanhia das Letras.

SEGATO, Rita Laura (1991). "U ma Vocação de M inoria: A Expansão dos Cultos Afro-Brasileiros na Argentina como Processo de Re-Etnicização". D ados, ããããã, pp. 240-278.

SILVA, Vagner G \& \& AM ARAL, Rita deC ássia (1994). A Cor do A xé: Brancos eN egrosno Candomblé de São Paulo. Reunião da ABA, N iterói. 


\begin{tabular}{|c|c|c|c|}
\hline \multicolumn{4}{|c|}{ Anexo I - ORIXÁSDO BATUQUE DO RIO GRANDE DO SUL } \\
\hline Orixá & Atribuição & Símbolos & Cores das roupas \\
\hline Bará & $\begin{array}{l}\text { dono das encruzilhadas; abridor } \\
\text { dos caminhos; Representa a força } \\
\text { vital que movimenta o universo. } \\
\text { M ensageiro dos orixás; orixá da } \\
\text { sensualidade. }\end{array}$ & $\begin{array}{l}\text { C have, foice, moedas, corrente, } \\
\text { tridente }\end{array}$ & vermelha \\
\hline O gum & $\begin{array}{l}\text { dono do trabal ho em metal e da } \\
\text { agricultura, guerreiro (demanda) }\end{array}$ & $\begin{array}{l}\text { Ferramentas em geral, espada, } \\
\text { faca, bigorna, martelo, mal ho, } \\
\text { lança, lima. }\end{array}$ & verde e vermelho ou verde \\
\hline Iansã & $\begin{array}{l}\text { dona dos raios, ventos, } \\
\text { tempestades e das águas }\end{array}$ & Espada, taça, pulseira, alianças & $\begin{array}{l}\text { vermel ho e branco, laranja ou } \\
\text { vermel ho }\end{array}$ \\
\hline Xangô & $\begin{array}{l}\text { orixá do trovão, da justiça e do } \\
\text { fogo }\end{array}$ & Balança, machado (duplo) e livro & vermelho e branco \\
\hline Ibeji & $\begin{array}{l}\text { protetores das crianças, doenças } \\
\text { infantis }\end{array}$ & $\begin{array}{l}\text { Bicos, balões, brinquedos, } \\
\text { mamadeira }\end{array}$ & $\begin{array}{l}\text { azul marinho, rosa, branco ou } \\
\text { vermelho, branco e amarelo }\end{array}$ \\
\hline Obá & sangue, ouvido, dona do lar & $\begin{array}{l}N \text { avalha, roda de madeira, timão, } \\
\text { orelha }\end{array}$ & rosa, marrom \\
\hline O dé/O tim & O rixás da caça, fala, sono & Arco e flecha, cântaro, bodoque & $\begin{array}{l}\text { azul marinho ( } 0 \text { dé) e marrom } \\
(0 \text { tim) }\end{array}$ \\
\hline
\end{tabular}




\begin{tabular}{|c|c|c|c|}
\hline O ssanha & $\begin{array}{l}\text { dono das folhas, protetor de } \\
\text { doenças internas, pernas, ossos }\end{array}$ & $\begin{array}{l}\text { M uleta, tesoura, agulha, linha de } \\
\text { coser }\end{array}$ & verde \\
\hline Xapanã & $\begin{array}{l}\text { protetor de doenças epidêmicas } \\
\text { (varíola, lepra, cólera) }\end{array}$ & V assoura, corrente de aço & preto e vermelho e roxo ou lilás \\
\hline Oxum & $\begin{array}{l}\text { dona da água doce, ouro, riqueza, } \\
\text { amor, vida }\end{array}$ & $\begin{array}{l}\text { Leque, espelho, dinheiro, } \\
\text { corrente dourada, pente }\end{array}$ & $\begin{array}{l}\text { amarelo de uma das três } \\
\text { tonalidades (claro, gema e } \\
\text { escuro) }\end{array}$ \\
\hline Iemanjá & $\begin{array}{l}\text { dona dos mares, maternidade e } \\
\text { da fertilidade }\end{array}$ & $\begin{array}{l}\text { Âncora, barco, remo, anel, } \\
\text { brincos, perfumes }\end{array}$ & azul claro \\
\hline Oxalá & $\begin{array}{l}\text { pai de todos os orixás, vida, paz, } \\
\text { visão }\end{array}$ & $\begin{array}{l}\text { Bastão (paxorô), pomba (iofá), } \\
\text { olho de vidro (orunmilá) }\end{array}$ & branco \\
\hline Orixá & Animais sacrificiais & Comidas oferecidas & $\begin{array}{c}\text { Correspondência com santo } \\
\text { católico }\end{array}$ \\
\hline Bará & bode, galo vermelho. & $\begin{array}{l}\text { M ilho torrado e batatas assadas, } \\
\text { pipoca. }\end{array}$ & $\begin{array}{l}\text { S. Antônio, S. Pedro e São } \\
\text { Benedito }\end{array}$ \\
\hline O gum & bode escuro, galo vermelho & Churrasco, com farofa (mamiã) & $\begin{array}{l}\text { São Jorge no Sul, Santo Antônio, } \\
\text { na Bahia }\end{array}$ \\
\hline lansã & $\begin{array}{l}\text { cabra cor de laranja e galinha } \\
\text { vermelha }\end{array}$ & Acarajé, pipocas, batata doce frita & S. Bárbará \\
\hline Xangô & carneiro, galo e pombos brancos & Amalá & $\begin{array}{l}\text { Jovem: São M iguel Arcanjo. } \\
\text { Velho: } \\
\text { São Jerônimo }\end{array}$ \\
\hline Ibeji & não recebem sacrifício & Somente doces e balas & São C osme e São D amião \\
\hline
\end{tabular}




\begin{tabular}{|l|l|l|l|}
\hline O bá & $\begin{array}{l}\text { galinha cinza, cabra marrom, } \\
\text { mocha e não } \\
\text { coberta }\end{array}$ & C anjica amarela, abacaxi & Santa C atarina \\
\hline O dé/O tim & porco, galo carijó & $\begin{array}{l}\text { Farinha de mandioca e mel, } \\
\text { costela de porco frita }\end{array}$ & $\begin{array}{l}\text { O dé: São Sebastião O tim: Santa } \\
\text { Efigênia }\end{array}$ \\
\hline O ssanha & bode, galo arrepiado & Batata cozida (apeté) & São J osé, Santo O nofre \\
\hline Xapanã & $\begin{array}{l}\text { bode com aspas de qualquer cor } \\
\text { menos } \\
\text { preto, galo prateado } \\
\text { pipoca }\end{array}$ & $\begin{array}{l}\text { Jovem: São Lázaro Velho: Cristo } \\
\text { das Chagas }\end{array}$ \\
\hline Oxum & $\begin{array}{l}\text { cabra, galinha amarela } \\
\text { Iemanjá }\end{array}$ & $\begin{array}{l}\text { C anjica amarela, } \\
\text { doces, quindins }\end{array}$ & $\begin{array}{l}\text { N. S. da Conceição, N . S. } \\
\text { Aparecida }\end{array}$ \\
\hline Oxalá & cabra, galinha cabra e galinha branca & C anjica, merengue, cocada & N. S. dos N avegantes \\
\hline
\end{tabular}




\begin{tabular}{|c|c|c|c|}
\hline & ENTIDADES & COMIDAS & SINCRETISMO \\
\hline & $\begin{array}{l}\text { O gum } \\
\text { (beira-mar, das matas, da rua, } \\
\text { tira-teima } \\
\text { rompe-mato, tibiri) }\end{array}$ & churrasco/cerveja & São Jorge \\
\hline \multirow[t]{2}{*}{ D } & lansã (mata, cachoeira) & pipoca/frutas & Santa Bárbara \\
\hline & Xangô (pedreira) & amalá/frutas & São J erônimo \\
\hline \multirow[t]{3}{*}{$\mathrm{E}$} & Oxossi (mata) & costela de porco & São Sebastião \\
\hline & Xapanã (mata) & frutas & São Lázaro \\
\hline & $\begin{array}{l}\text { Oxum } \\
\text { (cachoeira, água doce) }\end{array}$ & $\begin{array}{l}\text { canjica amarela } \\
\text { (em geral) }\end{array}$ & N ossa Senhora \\
\hline \multirow[t]{2}{*}{0} & Lemanjá (água) & canjica branca & N.S. N avegantes \\
\hline & Oxalá (ar) & canjica branca & Jesus C risto \\
\hline \multicolumn{4}{|l|}{$\mathrm{R}$} \\
\hline & Pretos Velhos & $\mathrm{s}$ & $\mathrm{s}$ \\
\hline \multirow[t]{2}{*}{1} & Pai Antônio & $\mathrm{E}$ & $\mathrm{E}$ \\
\hline & Pai M atias & M & M \\
\hline \multirow[t]{2}{*}{ G } & Pai Cipriano & & \\
\hline & Pai J oaquim & $\mathrm{s}$ & $\mathrm{s}$ \\
\hline E & Pai João & I & I \\
\hline
\end{tabular}




\begin{tabular}{|c|c|c|c|}
\hline & Pai Jacó & $\mathrm{N}$ & $\mathrm{N}$ \\
\hline \multirow[t]{3}{*}{ M } & Pai Antônio do Congo & C & C \\
\hline & Pai M oçambique & $\mathrm{R}$ & $\mathrm{R}$ \\
\hline & Pai Thomás & $E$ & $E$ \\
\hline \multirow[t]{2}{*}{ A } & Pai M iguel das Almas & $\mathrm{t}$ & $\mathrm{T}$ \\
\hline & Pai João de Angola & I & 1 \\
\hline \multirow[t]{2}{*}{$\mathrm{F}$} & Pai Benedito & $\mathrm{S}$ & $\mathrm{S}$ \\
\hline & Pai M iguel de Aruanda & M & M \\
\hline \multirow[t]{2}{*}{$\mathrm{R}$} & & 0 & 0 \\
\hline & Pretas Velhas & & \\
\hline \multirow[t]{2}{*}{1} & M ãe M aria & $\mathrm{s}$ & $\mathrm{s}$ \\
\hline & M ãe $\mathrm{M}$ aria Conga & $\mathrm{E}$ & $\mathrm{E}$ \\
\hline \multirow[t]{2}{*}{ C } & M ãe Joaquina & M & $M$ \\
\hline & M ãe Benedita & & \\
\hline \multirow[t]{2}{*}{ A } & Tia Chica de Angola & $\mathrm{s}$ & $\mathrm{s}$ \\
\hline & Vovó Sebastiana & 1 & I \\
\hline \multirow[t]{2}{*}{$\mathrm{N}$} & Vovó Benedita & $\mathrm{N}$ & $\mathrm{N}$ \\
\hline & Vovó Catarina & $\mathrm{C}$ & $\mathrm{C}$ \\
\hline \multirow[t]{4}{*}{ A } & Vovó Cambinda & $\mathrm{R}$ & $\mathrm{R}$ \\
\hline & Vovó Luiza & $\mathrm{E}$ & $\mathrm{E}$ \\
\hline & & $T$ & $\mathrm{~T}$ \\
\hline & Cosmes (I beji) & I & I \\
\hline
\end{tabular}




\begin{tabular}{|c|c|c|c|}
\hline \multicolumn{2}{|l|}{ D } & $\mathrm{S}$ & $\mathrm{S}$ \\
\hline & Caboclos & M & M \\
\hline \multirow[t]{3}{*}{$\mathrm{E}$} & Pena Verde & 0 & 0 \\
\hline & Folha Verde & & \\
\hline & Iara & $\mathrm{S}$ & $\mathrm{S}$ \\
\hline \multirow[t]{2}{*}{0} & Jupira & E & E \\
\hline & Jurema & M & M \\
\hline \multirow[t]{2}{*}{$\mathrm{R}$} & Arranca-Toco & & \\
\hline & Sete Flechas & $\mathrm{s}$ & $\mathrm{S}$ \\
\hline \multirow[t]{2}{*}{1} & Rompe-M ato & 1 & 1 \\
\hline & Ventania & C & $\mathrm{C}$ \\
\hline \multirow[t]{2}{*}{ G } & Jussara & $\mathrm{R}$ & $\mathrm{R}$ \\
\hline & Pena Branca & $E$ & $E$ \\
\hline \multirow[t]{2}{*}{$E$} & U birajara Peito de Aço & $T$ & $T$ \\
\hline & Tupinambá & 1 & 1 \\
\hline \multirow[t]{3}{*}{ M } & Tupi & $\mathrm{S}$ & $\mathrm{S}$ \\
\hline & Tupã & M & M \\
\hline & U birajara & 0 & 0 \\
\hline \multirow[t]{2}{*}{1} & U biratã & & \\
\hline & Aimoré & $\mathrm{s}$ & $\mathrm{s}$ \\
\hline \multirow[t]{2}{*}{$\mathrm{N}$} & Guaraci & $\mathrm{E}$ & $E$ \\
\hline & Água Branca & M & M \\
\hline
\end{tabular}




\begin{tabular}{|c|l|c|c|}
\hline & Tamoio & S & S \\
\hline & Guarani & I & I \\
\hline I & Estrela do M ar & N & C \\
\hline G & Sereia do M ar & C & R \\
\hline E & Jandira & R & E \\
\hline N & Jacira & E & T \\
\hline A & Cabocla da Praia & t & I \\
\hline & Cabocla Sete O ndas & I & S \\
\hline & Estrela D 'Alva & S & M \\
\hline
\end{tabular}

Anexo III - ENTIDADES DA LINHA CRUZADA DO RIO GRANDE DO SUL

\begin{tabular}{|l|l|l|}
\hline & \multicolumn{2}{|c|}{ EN TID ADES } \\
\hline & EXUS & POM BAG IRAS \\
\hline & Tiriri & D a Estrada \\
\hline & M arabô & D as Almas \\
\hline & sete Cruzeiros & Rainha das Sete Encruzilhadas \\
\hline & D estranca Ruas & D as Sete Saias \\
\hline & Rei das Sete Encruzilhadas & M aria Padilha \\
\hline
\end{tabular}




\begin{tabular}{|c|c|c|}
\hline & Tranca Ruas & Cigana do Acampamento \\
\hline \multirow[t]{2}{*}{$R$} & Da Porteira & M enina \\
\hline & Zé Pelintra & do 0 riente \\
\hline \multirow[t]{2}{*}{ U } & Pantera N egra & Rosa Vermelha \\
\hline & Da Capa Preta & \\
\hline \multirow[t]{2}{*}{ Z } & Q uebra-G alho & \\
\hline & Ventania & \\
\hline \multirow[t]{2}{*}{$E$} & Calunga & \\
\hline & Sete Pedras & \\
\hline \multirow[t]{2}{*}{1} & Sete $\mathrm{C}$ haves & \\
\hline & sete Portas & \\
\hline \multirow[t]{2}{*}{$R$} & Tranca Tudo & \\
\hline & \multicolumn{2}{|c|}{ CORES } \\
\hline \multirow[t]{3}{*}{0} & vermelho e preto & vermelho e preto \\
\hline & preto & preto \\
\hline & Exu Pagão & \\
\hline c & Exu do Cemitério & \\
\hline $\mathrm{E}$ & Pinga Fogo & D as Almas \\
\hline M & Caveira & Do Forno \\
\hline 1 & Tata Caveira & $\mathrm{M}$ aria $\mathrm{Q}$ uitéria \\
\hline$T$ & & M aria M ulambo \\
\hline É & Da M eia-N oite & \\
\hline
\end{tabular}




\begin{tabular}{|c|c|c|}
\hline $\mathrm{R}$ & Exu Lanan & \\
\hline 1 & Quilombô & \\
\hline \multirow[t]{4}{*}{0} & & \\
\hline & \multicolumn{2}{|c|}{ CORES } \\
\hline & vermelho e preto & vermelho e preto \\
\hline & preto & preto \\
\hline \multicolumn{3}{|l|}{$\mathrm{P}$} \\
\hline $\mathrm{R}$ & Do Lodo & D a Praia \\
\hline A & Mare & Cigana da Praia \\
\hline \multicolumn{3}{|l|}{1} \\
\hline \multirow[t]{3}{*}{ A } & \multicolumn{2}{|c|}{ CORES } \\
\hline & preto & preto \\
\hline & vermelho e preto & vermelho e preto \\
\hline \multirow[t]{8}{*}{ MATA } & Pantera N egra & Tucuara \\
\hline & \multicolumn{2}{|c|}{ CORES } \\
\hline & preto & preto \\
\hline & \multicolumn{2}{|c|}{ COMIDAS SECAS } \\
\hline & milho torrado & pipoca \\
\hline & 7 batatas assadas & 7 batatas assadas \\
\hline & $\begin{array}{l}\text { farofa de farinha de mandioca torrada com } \\
\text { dendê }\end{array}$ & \\
\hline & \multicolumn{2}{|c|}{ SANGUE } \\
\hline
\end{tabular}




\begin{tabular}{|l|l|l|}
\hline & galos vermelhos ou pretos & galinhas vermelhas ou pretas \\
\hline & pombos & pombas \\
\hline & bodes escuros & cabras pretas, marrons \\
\hline & \multicolumn{2}{|c|}{ BEBID AS } \\
\hline & cachaça, licores & champanhe, licores \\
\hline
\end{tabular}

